\title{
Development and validation of RP-HPLC method for estimation of brexpiprazole in its bulk and tablet dosage form using Quality by Design approach
}

\author{
Amol S. Jagdale ${ }^{1}$, Nilesh S. Pendbhaje ${ }^{2}$, Rupali V. Nirmal ${ }^{1 *}$, Poonam M. Bachhav ${ }^{1}$ and Dayandeo B. Sumbre ${ }^{1}$
}

\begin{abstract}
Background: A new, sensitive, suitable, clear, accurate, and robust reversed-phase high-performance liquid chromatography (RP-HPLC) method for the determination of brexpiprazole in bulk drug and tablet formulation was developed and validated in this research. Surface methodology was used to optimize the data, with a three-level Box-Behnken design. Methanol concentration in the mobile phase, flow rate, and $\mathrm{pH}$ were chosen as the three variables. The separation was performed using an HPLC method with a UV detector and Openlab EZchrom program, as well as a Water spherisorb $C_{18}$ column $(100 \mathrm{~mm} \times 4.6 ; 5 \mathrm{~m})$. Acetonitrile was pumped at a flow rate of $1.0 \mathrm{~mL} / \mathrm{min}$ with a $10 \mathrm{mM}$ phosphate buffer balanced to a $\mathrm{pH}$ of 2.50 .05 by diluted OPA $(65: 35 \% \mathrm{~V} / \mathrm{v})$ and detected at $216 \mathrm{~nm}$.
\end{abstract}

Result: The developed RP-HPLC method yielded a suitable retention time for brexpiprazole of 4.22 min, which was optimized using the Design Expert-12 software. The linearity of the established method was verified with a correlation coefficient $\left(r^{2}\right)$ of 0.999 over the concentration range of $5.05-75.75 \mathrm{~g} / \mathrm{mL}$. For API and formulation, the percent assay was $99.46 \%$ and $100.91 \%$, respectively. The percentage RSD for the method's precision was found to be less than 2.0\%. The percentage recoveries were discovered to be between 99.38 and $101.07 \% .0 .64 \mu \mathrm{g} / \mathrm{mL}$ and $1.95 \mathrm{\mu g} / \mathrm{mL}$ were found to be the $L O D$ and $L O Q$, respectively.

Conclusion: The developed and validated RP-HPLC system takes less time and can be used in the industry for routine quality control/analysis of bulk drug and marketed brexpiprazole products.

Keywords: RP-HPLC, QbD, Brexpiprazole, Acetonitrile, Development, Validation

\section{Background}

Brexpiprazole is 7-[4-[4-(1-benzothiophen-4-yl) piperazin-1-yl] piperazin-1-yl] piperazin-1-yl] piperazin1-yl] piperazin-1-yl] piperazin-1-yl] piperazin-1 butoxy] However, The USFDA approved quinolin-2 (1H)-one in 2015, and it is marketed as Rexulti, a generic name coined by Otsuka in Japan and marketed by Lundbeck in the USA for the treatment of schizophrenia as a

\footnotetext{
* Correspondence: rupalinirmalcpn@gmail.com

1 MVPs College of Pharmacy, Nashik-422 002, Department of Pharmaceutical

Chemistry, Savitribai Phule Pune University, Pune, MS, India

Full list of author information is available at the end of the article
}

monotherapy and as an adjunctive treatment to antidepressants in the treatment of major depressive disorder [1-5]. Early treatment with aripiprazole can result in problematic akathisia. Brexpiprazole may be less likely than aripiprazole to induce akathisia. This will be a big benefit, but there is not much experience with the drug yet. Brexpiprazole, like aripiprazole, is a partial agonist of the dopamine D2 receptor and has mild effects on QTc. Brexpiprazole is likely to have a wide dose range in clinical practice due to the function of CYP2D6 in its metabolism [6-14]. 


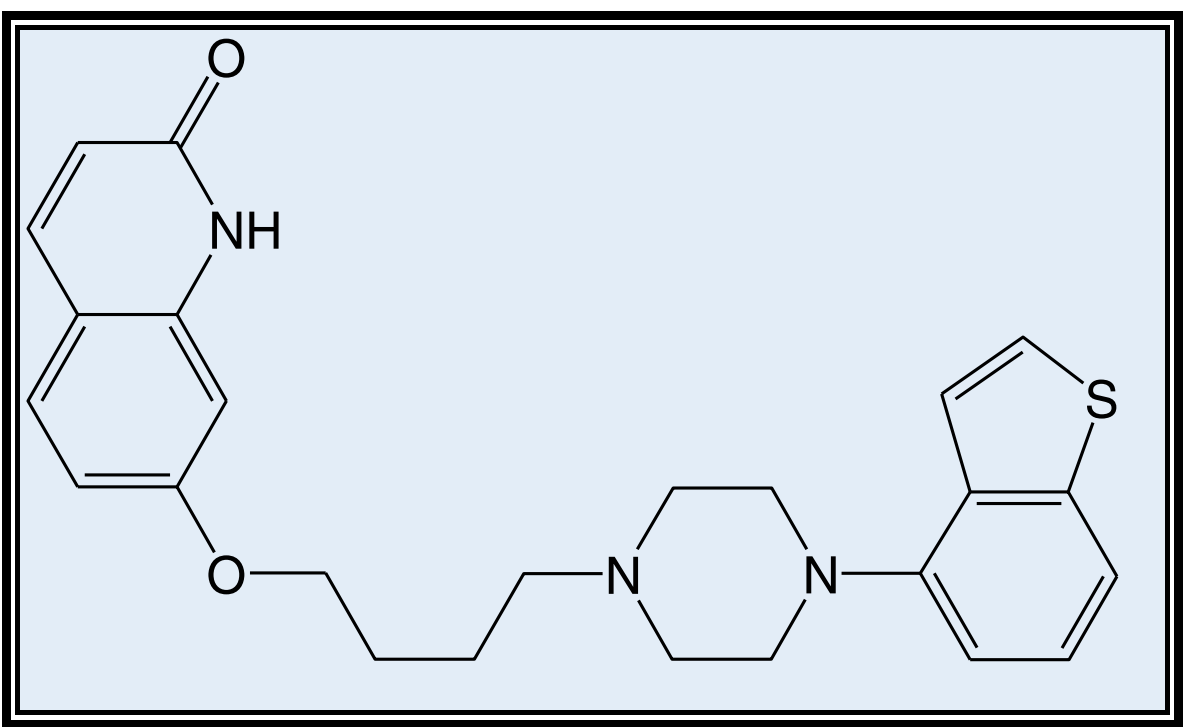

Fig. 1 Molecular structure of brexpiprazole

According to a literature review, there are few publications on UV-visible spectroscopy and HPLC, but no one has used Quality by Design. To ensure process consistency throughout the product lifecycle, simple validated RP-HPLC methods for the determination of brexpiprazole in pharmaceutical dosage forms must be established using the Quality by Design $(\mathrm{QbD})$ approach as per ICH Q8 (R2) guidelines [8, 15-19].

\section{Methods}

\section{Materials and reagents}

Alkem Laboratories Limited, Mumbai, donated brexpiprazole (see Fig. 1). Merck provided HPLC grade methanol, acetonitrile, orthophosphoric acid (OPA), and analytical grade ethanol, DMF, DMSO, and $\mathrm{HCl}$. Siddhi Lab provided the HPLC grade water.

\section{Instrumentation and software}

An Agilent HPLC system with DEAX02386 pump and autosampler with UV-visible detector served as the chromatographic system (DEACX16446). For data collection and processing, the chromatograms were registered using Openlab EZChrom on a Windows-based computer system. Brexpiprazole concentrations were determined using a HyPURITY $\mathrm{C}_{18}(100 \mathrm{~mm} \times 4.6 \mathrm{~mm} \mathrm{ID}$, particle size $5 \mu$ ) column.

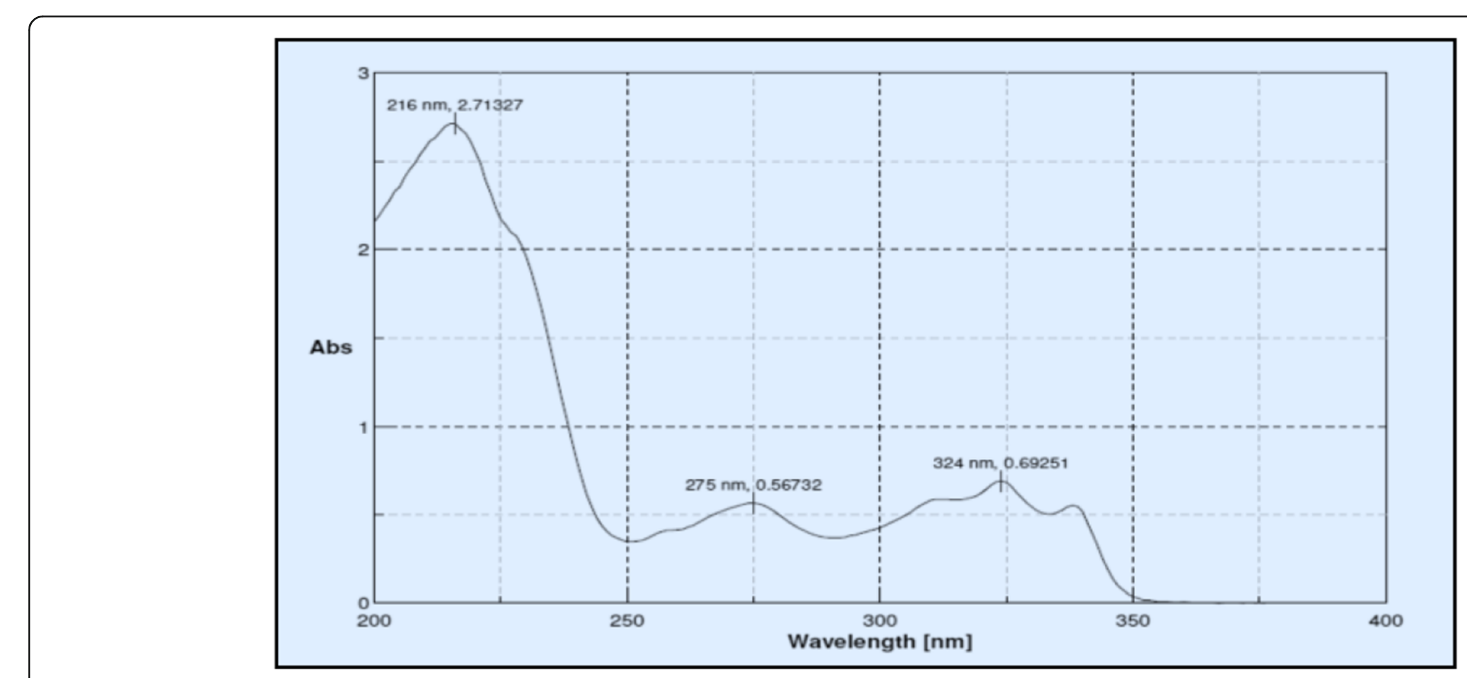

Fig. 2 UV spectrum of brexpiprazole in methanol 
Table $13^{3}$ Box-Behnken full factorial design of DOE

\begin{tabular}{|c|c|c|c|c|c|c|}
\hline Runs & $\begin{array}{l}\text { Factor } 1 \\
\text { A: ACN }\end{array}$ & $\begin{array}{l}\text { Factor } 2 \\
\text { B: } p H\end{array}$ & $\begin{array}{l}\text { Factor } 3 \\
\text { C: flow rate }\end{array}$ & $\begin{array}{l}\text { Response } 1 \\
\text { R.T. (min) }\end{array}$ & $\begin{array}{l}\text { Response } 2 \\
\text { Asymmetry }\end{array}$ & $\begin{array}{l}\text { Response } 3 \\
\text { TP }\end{array}$ \\
\hline 1 & 65 & 2.50 & 1.0 & 4.22 & 1.34 & 3662 \\
\hline 2 & 75 & 3.00 & 1.0 & 4.03 & 1.51 & 4067 \\
\hline 3 & 75 & 2.50 & 0.8 & 5.04 & 1.37 & 3945 \\
\hline 4 & 65 & 3.00 & 0.8 & 5.33 & 1.3 & 2986 \\
\hline 5 & 65 & 2.00 & 0.8 & 5.37 & 1.43 & 3305 \\
\hline 6 & 75 & 2.50 & 1.2 & 3.41 & 1.36 & 3377 \\
\hline 7 & 65 & 3.00 & 1.2 & 3.54 & 1.45 & 3461 \\
\hline 8 & 65 & 2.50 & 1.0 & 4.22 & 1.34 & 3662 \\
\hline 9 & 55 & 3.00 & 1.0 & 4.61 & 1.02 & 1566 \\
\hline 10 & 55 & 2.50 & 1.2 & 3.84 & 1.07 & 1598 \\
\hline 11 & 55 & 2.00 & 1.0 & 4.83 & 0.93 & 1266 \\
\hline 12 & 65 & 2.00 & 1.2 & 3.6 & 1.41 & 2753 \\
\hline 13 & 65 & 2.50 & 1.0 & 4.23 & 1.34 & 3662 \\
\hline 14 & 65 & 2.50 & 1.0 & 4.23 & 1.34 & 3662 \\
\hline 15 & 55 & 2.50 & 0.8 & 5.66 & 0.99 & 1755 \\
\hline 16 & 75 & 2.00 & 1.0 & 4.13 & 1.52 & 3246 \\
\hline 17 & 65 & 2.50 & 1.0 & 4.22 & 1.34 & 3662 \\
\hline
\end{tabular}

\section{$Q b D$ software}

Design Expert ${ }^{\oplus}$ software (Design Expert trial version 12.0.10.0; State-Ease Inc., Minneapolis, MN, USA)

\section{Preparations of solutions}

Preparation of standard stock solution

The standard solution was made by dissolving $10 \mathrm{mg}$ of brexpiprazole in a $100-\mathrm{mL}$ clean and dry volumetric flask, then adding approximately $70 \mathrm{~mL}$ of methanol to fully dissolve it and fill the flask to the mark with methanol $(100 \mu \mathrm{g} / \mathrm{mL})$.

Table 2 Experimental results and selected method conditions

\begin{tabular}{ll}
\hline $\begin{array}{l}\text { Parameter/ } \\
\text { condition }\end{array}$ & Description \\
\hline $\begin{array}{l}\text { Injection } \\
\text { volume }\end{array}$ & $20 \mu \mathrm{L}$ \\
$\begin{array}{l}\text { Wavelength } \\
\text { Mobile phase }\end{array}$ & $216 \mathrm{~nm}$ \\
Program & Acetonitrile: buffer $(65: 35 \% \mathrm{v} / \mathrm{v})$ \\
$\begin{array}{l}\text { Flow rate } \\
\text { Isocratic } \\
\text { temp }\end{array}$ & $1.0 \mathrm{~mL} / \mathrm{min}$ \\
Run time & $30^{\circ} \mathrm{C}$ \\
Buffer & $7 \mathrm{~min}$ \\
& $10 \mathrm{mM}$ potassium dihydrogen orthophosphate in \\
\hline
\end{tabular}

\section{Sample preparation}

Ten milligrams brexpiprazole was correctly weighed and transferred to a $100-\mathrm{mL}$ volumetric flask. Fifty milliliters diluent was added and sonicated to fully remove it. Using diluent, dilute the mixture by another 10 to $20 \mathrm{~mL}$.

\section{Preparation of diluted OPA}

Pipette $5 \mathrm{~mL}$ of OPA into a $50-\mathrm{mL}$ volumetric flask and top up with water to reach the desired amount. Sonicate for $5 \mathrm{~min}$ after thoroughly mixing.

\section{Preparation of $1.0 \%$ OPA in water}

One milliliter OPA was blown out of the solution and moved to a 100-mL volumetric flask, which was filled to the mark with water. Sonicate for $5 \mathrm{~min}$ after thoroughly mixing.

\section{Preparation of $10.00 \mathrm{mM}$ phosphate buffer in water}

Weigh $1.36 \mathrm{~g}$ of OPA and dissolve it in $1000 \mathrm{~mL}$ of water, adjusting the $\mathrm{pH}$ to $2.0( \pm) 0.05$ with the diluted OPA solution.

\section{Determination of detection wavelength}

Between 200 and $400 \mathrm{~nm}$, the standard solution was scanned. As shown in Fig. 2, the wavelength of maximum absorption for drug was determined to be 216 nm. 
Table 3 The formula for one tablet

\begin{tabular}{lll}
\hline Sr. No. & Ingredients & Weight $\mathbf{( m g )}$ \\
\hline 1 & API & 4.0 \\
2 & Lactose & 134 \\
3 & Magnesium stearate & 4.0 \\
4 & Talc & 4.0 \\
5 & Starch & 4.0 \\
Total weight & & $\mathbf{1 5 0}$ \\
\hline
\end{tabular}

\section{Method development by QbD approach Application of design of experiments for method optimization}

To investigate the effect of three factors on the two primary response variables, 33 randomized response surface designs with a Box-Behnken design were used with 17 trial runs. Three variables were analyzed at three levels in this design, and experimental trials were conducted in all three possible combinations. Flow rates (X1), $\mathrm{pH}(\mathrm{X} 2)$, and mobile phase composition (X3) were designated as independent variables, while retention time (RT), asymmetry, and theoretical plates were designated as dependent variables. The data was then entered into the Design Expert 12.0.10.0 software and evaluated using the ANOVA test. To assess the effect of flow rate, $\mathrm{pH}$, and mobile phase composition on dependent variables, the results were subjected to the 3-dimensional response surface methodology. Table 1 shows the likely trial runs using $3^{3}$ Box-Behnken designs. Table 2 shows the experimental results and selected method conditions.

\section{Analysis of the sample}

Brexpiprazole drug (API) The drug sample solution was prepared by liquifying $10 \mathrm{mg}$ of brexpiprazole API into a $100-\mathrm{mL}$ volumetric flask, adding $70 \mathrm{~mL}$ of methanol to fully melt it by sonication, and then adjusting the volume with solvents $(100 \mathrm{~g} / \mathrm{mL})$. Filtered through a suitable filter, and a sufficient amount of the sample solution was discarded. Using methanol $(50 \mathrm{~g} / \mathrm{mL})$, dilute 5 $\mathrm{mL}$ of the filtrate solution to $10 \mathrm{~mL}$.

Tablet formulation Keep in mind, in the market, there is a tablet called Rexulti. However, it is not available in India. There are three doses available: 1,2 , and $4 \mathrm{mg}$. The sample preparation will be seen on a dosage of 4 mg, which is a higher dose. For preparing lab-level tablet mixture, approximately $150 \mathrm{mg}$ average weight is taken into account. The formula for one tablet is shown in Table 3.

Weigh $10 \mathrm{mg}$ of brexpiprazole powder into a $100-\mathrm{mL}$ flask, add about $70 \mathrm{~mL}$ of methanol to completely solubilize it by sonication, and complete volume up to spot with the methanol $(100 \mathrm{~g} / \mathrm{mL})$. Filtered through a suitable filter, and a sufficient amount of the sample solution was discarded. Five milliliters filtrate solution was diluted to $10 \mathrm{~mL}$ with methanol $(50 \mathrm{~g} / \mathrm{mL})$.

\section{Control strategy \\ Filtration study}

Filtration experiment using centrifuged (unfiltered) sample and filtered test solution. During the filtration process, $5 \mathrm{~mL}$
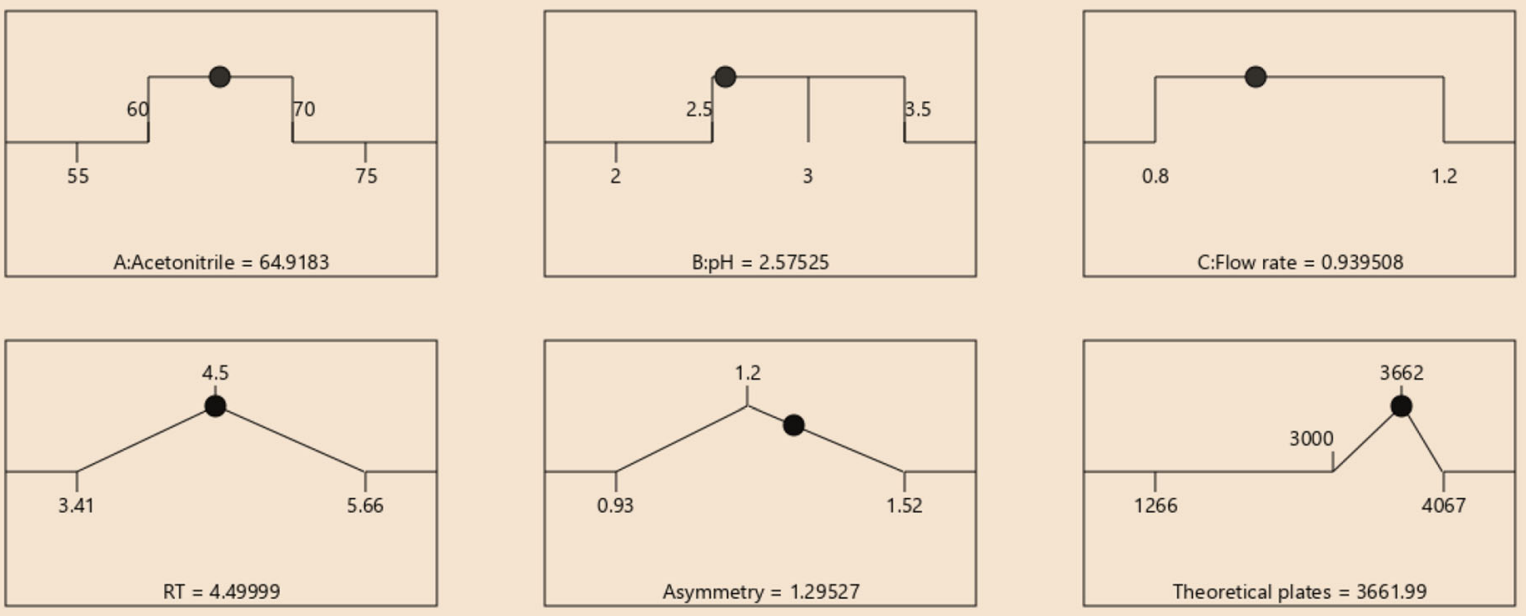

Fig. 3 Solutions for optimized run 


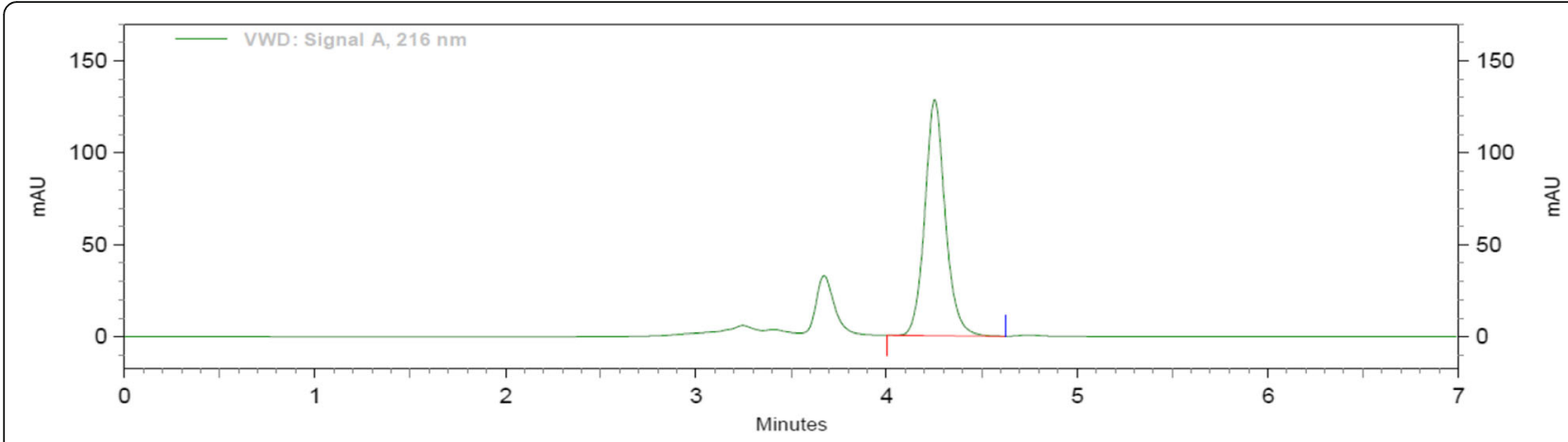

Fig. 4 Typical chromatogram obtained from optimized mobile phase

of the aliquot sample was discarded and $0.45 \mathrm{~m}$ PVDF 0.45 and $0.45 \mathrm{~m}$ Nylon syringe filters were used.

\section{Stability of analytical solution}

A stability analysis will be carried out on both the normal and test solutions. A test sample of Rexulti tablet will be used to determine the stability of the test solution. The stability test will be carried out in a standard laboratory environment.

The solution will be held in a brightly lit laboratory for 12 to $24 \mathrm{~h}$ before being analyzed. The discrepancy between the test solution's results at each stability time point and the original will be calculated for the test solution stability analysis. The discrepancy between the effects of the stability time point and the original will be calculated in a standard solution stability analysis.

\section{Method validation}

The developed method for estimating brexpiprazole was validated for the following parameters using $\mathrm{ICH}$ Q2 (R1) guidelines [20-25].

\section{Specificity}

To demonstrate the method's precision, the following solutions will be prepared and injected (double-checked the peak purity).

I. Blank (methanol as a diluent)

II. Brexpiprazole standard solution

III. Brexpiprazole sample solution

IV. Placebo treatments

\section{Linearity and range}

The statistical treatment of test results obtained by examination of samples with analyte concentrations around the claimed spectrum determines the analytical method's linearity. As a function of analyte concentration, the region is graphically plotted. Curve fitting percentages are measured.

\section{Accuracy (\%recovery)}

The accuracy will be tested in the range of 50 to $150 \%$ of the working concentration of $4 \mathrm{mg}$ strength. Every occurs solution will be prepared in triplicate. A placebo

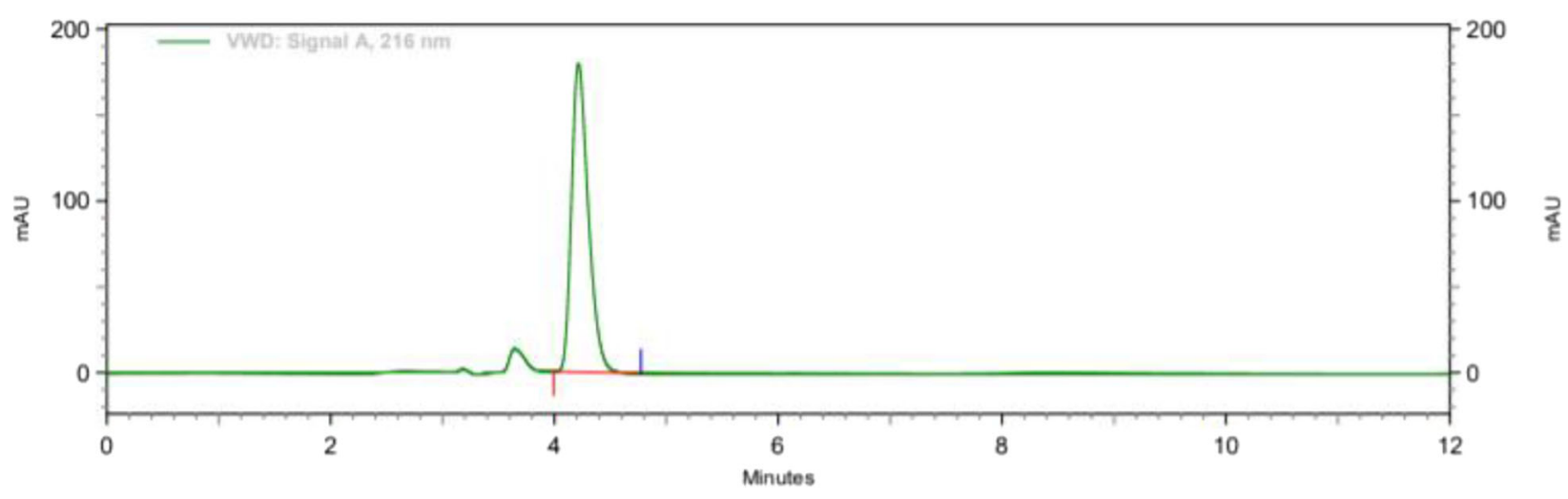

Fig. 5 Typical chromatogram of optimized run 
Table 4 Analytical data of optimized run

\begin{tabular}{lllll}
\hline Parameter & $\begin{array}{l}\text { R.T. } \\
(\mathbf{m i n})\end{array}$ & Area & Asymmetry & $\begin{array}{l}\text { Theoretical plate } \\
\text { (USP) }\end{array}$ \\
\hline Observation & 4.22 & $\begin{array}{l}31,495, \\
627\end{array}$ & 1.34 & 3662 \\
& & & &
\end{tabular}

will be included in the experiment. For each study, the percent recovery was determined.

\section{Precision}

I. There are two levels of precision: repeatability and intermediate precision. It is carried out on a sample API.

II. Repeatability (intraday precision)

III. Intermediate precision (interday precision)

\section{Robustness}

The API test sample was created from scratch. As shown below, these samples were injected under various chromatographic conditions.

- Flow rate changes ( $20 \%$ of the total)

- A change in wavelength $(3 \mathrm{~nm})$

- $\pm 2^{\circ} \mathrm{C}$ increase in column oven temperature

\section{Detection}

The limit of detection (LOD) and limit of quantification (LOQ) were calculated separately using the following equations based on the standard deviation of the $y$ intercept and the slope of the calibration curve, respectively.

$$
\mathrm{LOD}=3.3 \delta / \mathrm{S}, \mathrm{LOQ}=10 \delta / \mathrm{S}
$$

\section{Results}

\section{Optimization of mobile phase}

Methanol: water (70:30), acetonitrile: water (70:30), acetonitrile: $1 \%$ OPA in water (80:20), and acetonitrile: $10 \mathrm{mM}$ phosphate buffer were among the mobile phases that were optimised, shown in Fig. 3. Acetonitrile: 10 $\mathrm{mM}$ phosphate buffer adjusted $\mathrm{pH} 2.5$ by OPA (80:20), acetonitrile: $10 \mathrm{mM}$ phosphate buffer adjusted $\mathrm{pH} 2.5$ by OPA (65:35), acetonitrile: $10 \mathrm{mM}$ phosphate buffer adjusted pH 2.5 by OPA (65:35). As a result, chromatographic conditions in trial were used for process

Table 5 Design summary for optimization

\begin{tabular}{llll}
\hline Study type & Design type & $\begin{array}{l}\text { Design } \\
\text { model }\end{array}$ & $\begin{array}{l}\text { Total } \\
\text { runs }\end{array}$ \\
\hline $\begin{array}{l}\text { Response } \\
\text { surface }\end{array}$ & $\begin{array}{l}\text { Central composite } \\
\text { design }\end{array}$ & Quadratic & 17 \\
\hline
\end{tabular}

Table 6 Obtained solution for optimized formulation

\begin{tabular}{|c|c|c|c|c|c|c|}
\hline \multirow[t]{2}{*}{ Runs } & $\begin{array}{l}\text { Factor } \\
1\end{array}$ & $\begin{array}{l}\text { Factor } \\
2\end{array}$ & $\begin{array}{l}\text { Factor } \\
3\end{array}$ & $\begin{array}{l}\text { Response } \\
1\end{array}$ & $\begin{array}{l}\text { Response } \\
2\end{array}$ & $\begin{array}{l}\text { Response } \\
3\end{array}$ \\
\hline & $\begin{array}{l}\text { A: } \\
\text { ACN }\end{array}$ & $\mathrm{B}: \mathrm{pH}$ & $\begin{array}{l}\text { C: flow } \\
\text { rate }\end{array}$ & R.T. (min) & Asymmetry & TP \\
\hline 1 & 65 & 2.50 & 1.0 & 4.22 & 1.34 & 3662 \\
\hline
\end{tabular}

validation, as shown in Fig. 4: Acetonitrile: $10 \mathrm{mM}$ phosphate buffer modified pH 2.5 by OPA (65:35) provides a better peak, lower retention time, and tailing factor. Typical chromatogram of optimized run is shown in Fig. 5. Analytical data for typical chromatogram of optimized run are shown in Table 4.

\section{Optimization of various parameters for analysis of} brexpiprazole using HPLC (by using central composite design)

Design summary for optimization is given in Table 5 . Obtained solution for optimized formulation is given in Table 6.

\section{System suitability test (SST)}

It was observed from the data tabulated that the method complies with system suitability parameters. Hence, it can be concluded that the system suitability parameter meets the requirement of method validation. Typical chromatogram of SST for brexpiprazole is shown in Fig. 6. Analytical data of system suitability test are given in Table 7.

\section{Filter test}

Both filters PVDF and Nylon pass the criteria for filter study; hence, both filters can be used because \%absolute difference is NMT 2.0, and it follows acceptance criteria. Analytical data of filter test are given in tabular form in Table 8. Typical chromatogram of unfiltered sample, sample filtered through $0.45 \mu$ PVDF filter, and sample filtered through $0.45 \mu$ Nylon filter is shown in Figs. 7, 8, and 9 respectively.

\section{Solution stability}

Both standard solution and sample solution were found stable for $24 \mathrm{~h}$; hence, prepared solution can be used up to $24 \mathrm{~h}$. (User can check solution stability even after $24 \mathrm{~h}$ if he/she wants to inject solution after 24 h.) Analytical data are given in Table 9.

\section{Specificity}

Blank and placebo solution are not having interference at R.T. of brexpiprazole. Peak purity for both standard as well as sample was within limits. Sample solution exhibits the same R.T. as that of standard solution. Hence, developed chromatographic method 


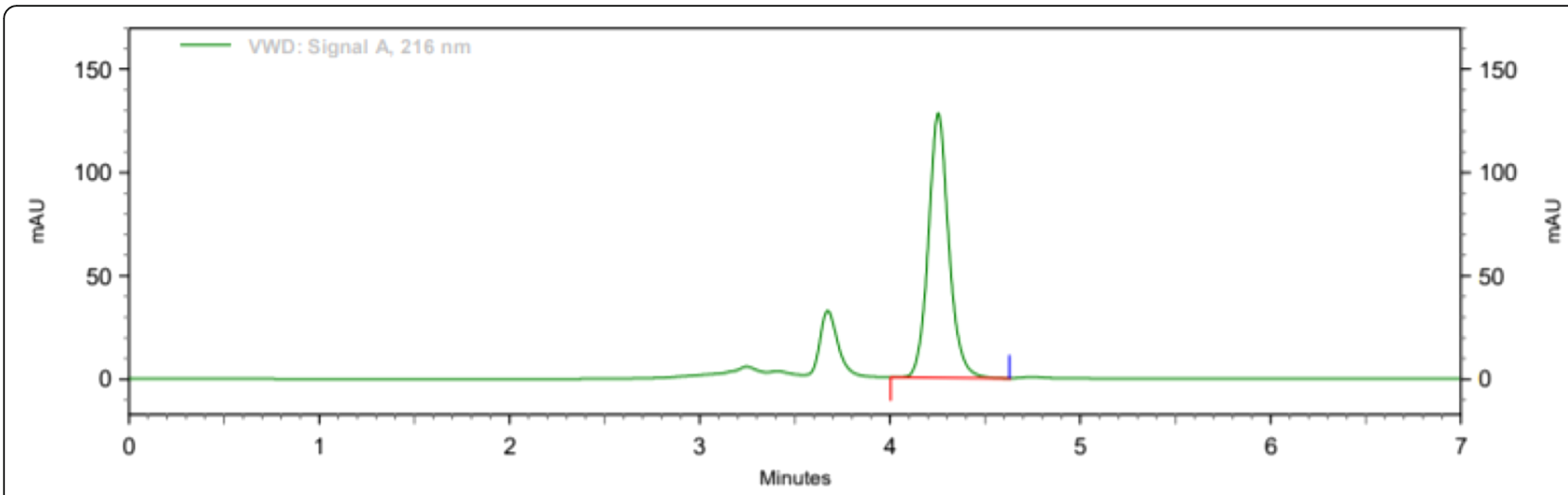

Fig. 6 Typical chromatogram of SST for brexpiprazole

passed the criteria for specificity. Result of specificity is given in Table 10.

\section{Accuracy (\%recovery)}

\%Recovery was found well within acceptance range (98.00 to $102.0 \%)$ at all three levels. Result and statistical data of accuracy are given in Table 11.

\section{Precision}

\%RSD for 12 samples (precision and intermediate precision samples) NMT $2.0 \%$. The \%RSD of method precision is 0.53 and 0.495 . Therefore, the HPLC method for the determination of brexpiprazole is precise. Analytical data of both precision of brexpiprazole is given in Table 12 .

\section{Linearity}

From the calibration curve, we had to conclude that brexpiprazole shows linear response in the range of $5.05-75.75 \mu \mathrm{g} / \mathrm{mL}$. The regression value was found well within the limit. Result and statistical data of linearity of brexpiprazole are given in Table 13. Linearity graph of brexpiprazole is shown in Fig. 10.

Table 7 Analytical data of system suitability test

\begin{tabular}{lll}
\hline Parameter & Acceptance criteria & Result \\
\hline \%RSD & NMT 2.0\%. & $\mathbf{0 . 3 5}$ \\
Theoretical plates & More than 2000 & $\mathbf{3 6 5 4}$ \\
Tailing factor & NMT 2.0 & $\mathbf{1 . 3 4}$ \\
\hline
\end{tabular}

\section{Conclusion}

Based on the calibration curve, we can deduce that brexpiprazole has a linear response in the 5.05$75.75 \mathrm{~g} / \mathrm{mL}$ range. The regression value was discovered to be well within the acceptable range. Data for calibration curve of brexpiprazole is shown in Table 14.

\section{Detection}

It may be calculated based on the standard deviation (SD) of the response and slope of the curve (S). Result of detection limit is given in Table 15 . Calibration curve of brexpiprazole for LOD and LOQ is given in Fig. 11.

\section{Robustness}

The robustness of an analytical method is determined by analysis of aliquots from homogenous lots by differing physical parameters that may differ but are still within the specified parameters of the assay. Analytical interpretation is given in Table 16.

Table 8 Analytical data of filter test

\begin{tabular}{|c|c|c|c|c|}
\hline Sample & Area & $\begin{array}{l}\% \\
\text { Absolute } \\
\text { difference }\end{array}$ & $\begin{array}{l}\text { Acceptance } \\
\text { criteria }\end{array}$ & Conclusion \\
\hline Unfiltered & $\begin{array}{l}16 \\
256 \\
478\end{array}$ & NA & $\begin{array}{l}\% \text { Absolute } \\
\text { difference } \\
\text { NMT } 2.0\end{array}$ & $\begin{array}{l}\text { Both PVDF and Nylon } \\
\text { filters passes the criteria } \\
\text { for filter study }\end{array}$ \\
\hline $\begin{array}{l}0.45 \mu \\
\text { PVDF } \\
\text { filter }\end{array}$ & $\begin{array}{l}16 \\
178 \\
521\end{array}$ & 0.48 & & \\
\hline $\begin{array}{l}0.45 \mu \\
\text { Nylon } \\
\text { filter }\end{array}$ & $\begin{array}{l}16 \\
152 \\
546\end{array}$ & 0.64 & & \\
\hline
\end{tabular}




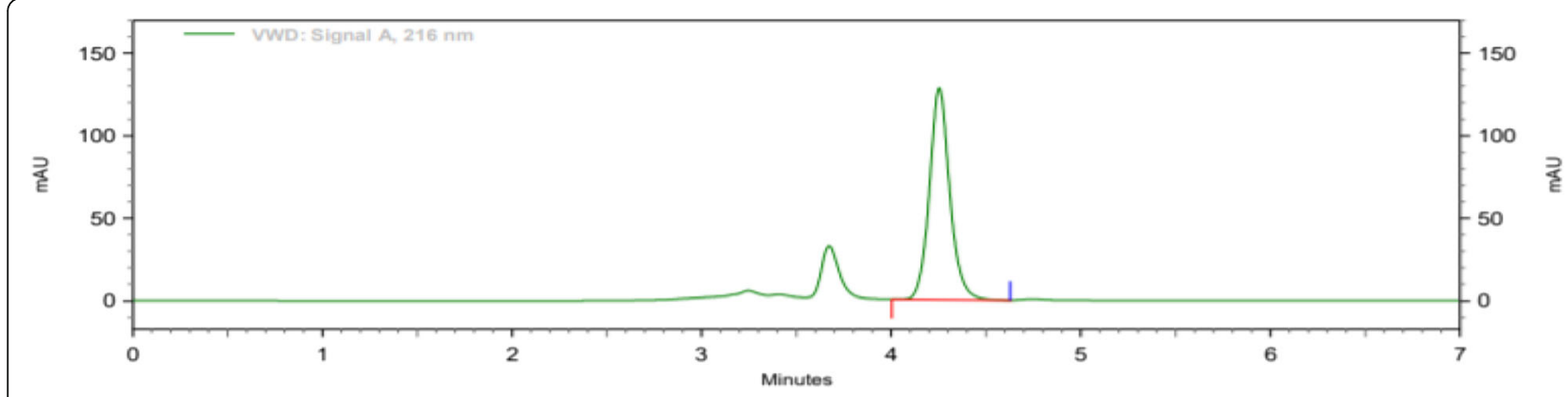

Fig. 7 Typical chromatogram of unfiltered sample

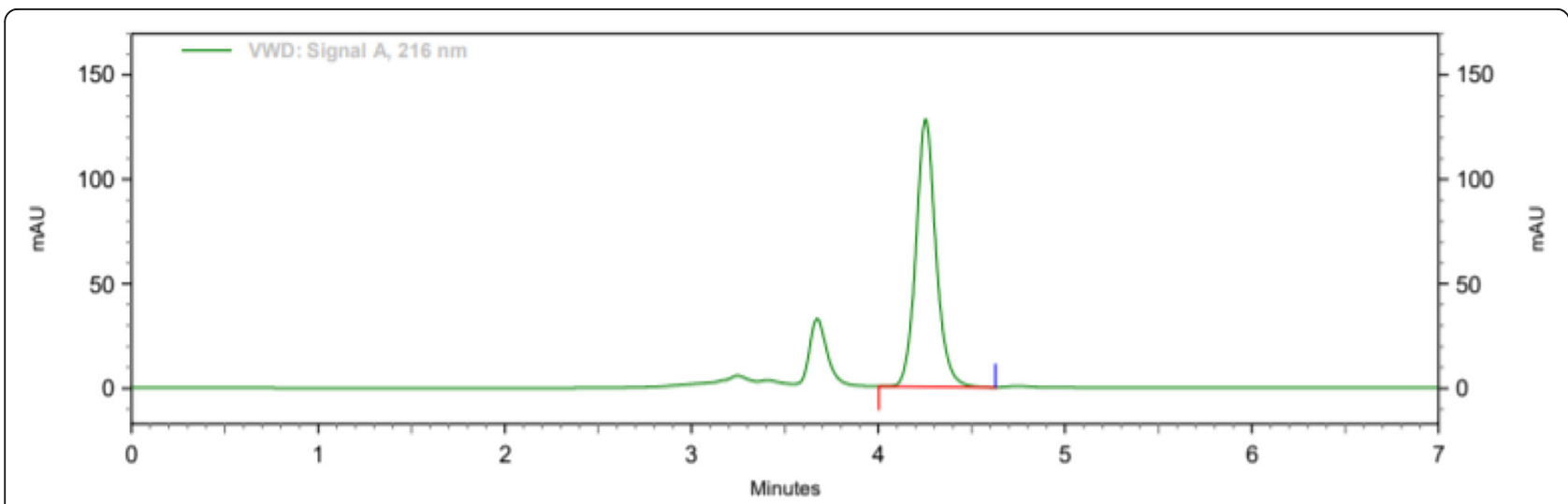

Fig. 8 Typical chromatogram of sample filtered through $0.45 \mu$ PVDF filter

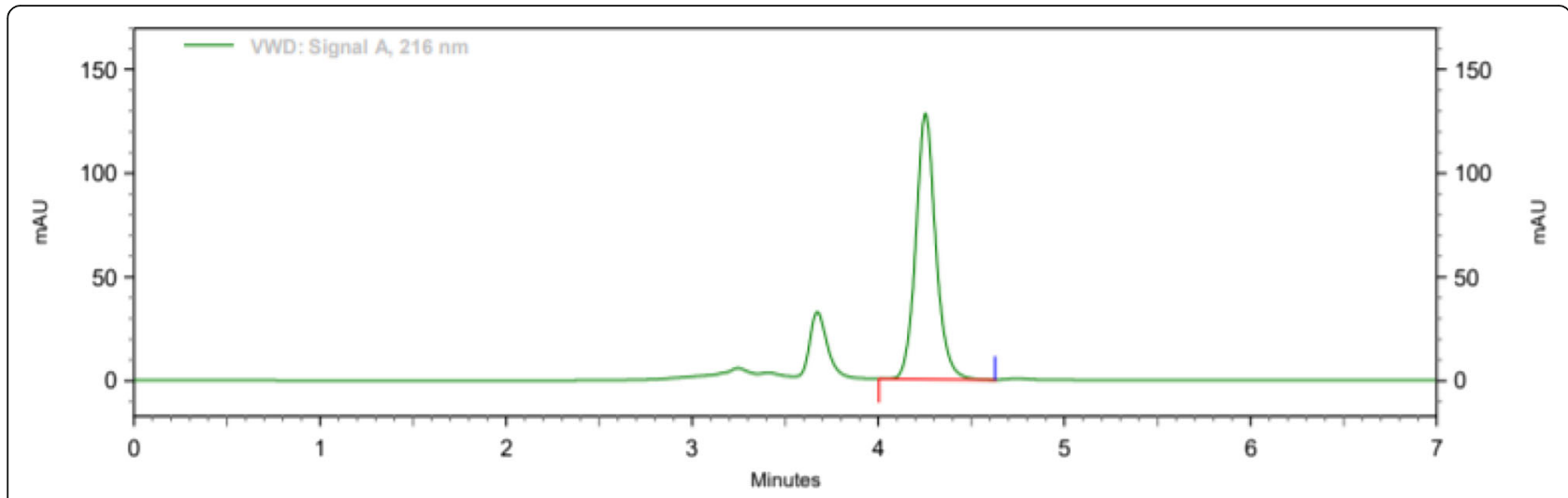

Fig. 9 Typical chromatogram of sample filtered through $0.45 \mu$ Nylon filter 
Table 9 Analytical data of brexpiprazole for solution stability

\begin{tabular}{|c|c|c|c|c|c|c|c|}
\hline \multicolumn{3}{|c|}{ Test solution } & \multicolumn{3}{|c|}{ Standard solution } & \multirow[t]{2}{*}{ Acceptance criteria } & \multirow[t]{2}{*}{ Conclusion } \\
\hline $\begin{array}{l}\text { Time } \\
\text { point }\end{array}$ & Area & $\begin{array}{l}\text { \% Absolute } \\
\text { difference }\end{array}$ & $\begin{array}{l}\text { Time } \\
\text { point }\end{array}$ & Area & $\begin{array}{l}\text { \% Absolute } \\
\text { difference }\end{array}$ & & \\
\hline Initial & $\begin{array}{l}16,238 \\
783\end{array}$ & NA & Initial & $\begin{array}{l}16,245 \\
895\end{array}$ & NA & $\begin{array}{l}\% \text { Absolute difference } \\
\text { NMT } 2.0\end{array}$ & $\begin{array}{l}\text { Both standard solution and sample solution } \\
\text { were found stable for } 24 \text { hours }\end{array}$ \\
\hline $12 \mathrm{~h}$ & $\begin{array}{l}16,217 \\
981\end{array}$ & 0.13 & $12 \mathrm{~h}$ & $\begin{array}{l}16,226 \\
483\end{array}$ & 0.12 & & \\
\hline $24 \mathrm{~h}$ & $\begin{array}{l}16,211 \\
870\end{array}$ & 0.17 & $24 \mathrm{~h}$ & $\begin{array}{l}16,216 \\
591\end{array}$ & 0.18 & & \\
\hline
\end{tabular}

Table 10 Results of specificity

\begin{tabular}{llll}
\hline Description & Observation & Acceptance criteria & Conclusion \\
\hline Blank & No interference at R.T. of brexpiprazole in blank & No interference at R.T. & $\begin{array}{l}\text { Developed chromatographic method } \\
\text { passed the criteria for specificity. }\end{array}$ \\
$\begin{array}{l}\text { Standard solution } \\
\text { Sample solution }\end{array}$ & Peak purity was 0.998 & Peak purity: NLT 0.95 & \\
Placebo & Peak purity was 0.998 & Peak purity: NLT 0.95 & \\
\hline
\end{tabular}

Table 11 Result and statistical data of accuracy

\begin{tabular}{lllllll}
\hline Level (\%) & Area & Added concentration & Recovered concentration & \% Recovery & Acceptance criteria & Conclusion \\
\hline 50 & $8,130,145$ & 25.50 & 25.75 & 100.98 & \% Recovery 98.00 to 102.0\% & \% Recovery was found well \\
& $8,123,654$ & 25.50 & 25.73 & 100.90 & within acceptance range \\
at all three levels. & & \\
100 & $8,133,254$ & 25.50 & 25.76 & 101.02 & \\
& $16,101,547$ & 51.00 & 51.00 & 100.00 & \\
150 & $16,158,482$ & 51.50 & 51.18 & 99.38 & \\
& $16,122,354$ & 51.00 & 51.07 & 100.14 & \\
\hline
\end{tabular}

Table 12 Data of precision of brexpiprazole

\begin{tabular}{lllll}
\hline Parameters & Intraday precision & Interday precision & Acceptance criteria & Conclusion \\
\hline Mean & $\mathbf{1 0 0 . 3 5 6}$ & $\mathbf{1 0 0 . 7 2}$ & \% RSD for the six samples NMT 2.0 & HPLC method for the determination \\
SD & 0.61941 & $\mathbf{0 . 4 9 8 8 2 5}$ & & of brexpiprazole is precise \\
$\%$ RSD & 0.617 & 0.495 & & \\
\hline
\end{tabular}


Table 13 Result and statistical data of linearity of brexpiprazole

\begin{tabular}{|c|c|c|c|c|}
\hline Level & Conc $(\mu \mathrm{g} / \mathrm{mL})$ & Area & Mean & \% RSD \\
\hline \multirow[t]{3}{*}{$10 \%$} & 5.05 & $1,594,696$ & $1,594,354$ & 0.029 \\
\hline & & $1,594,532$ & & \\
\hline & & $1,593,834$ & & \\
\hline \multirow[t]{3}{*}{$50 \%$} & 25.25 & $8,030,550$ & $8,030,485$ & 0.012 \\
\hline & & $8,031,450$ & & \\
\hline & & $8,029,456$ & & \\
\hline \multirow[t]{3}{*}{$100 \%$} & 50.5 & $16,092,802$ & $16,092,015$ & 0.004 \\
\hline & & $16,091,720$ & & \\
\hline & & $16,091,523$ & & \\
\hline \multirow[t]{3}{*}{$125 \%$} & 62.62 & $20,155,235$ & $20,142,362$ & 0.073 \\
\hline & & $20,126,230$ & & \\
\hline & & $20,145,621$ & & \\
\hline \multirow[t]{3}{*}{$150 \%$} & 75.75 & $24,235,366$ & $24,225,635$ & 0.040 \\
\hline & & $24,215,892$ & & \\
\hline & & $24,225,648$ & & \\
\hline
\end{tabular}

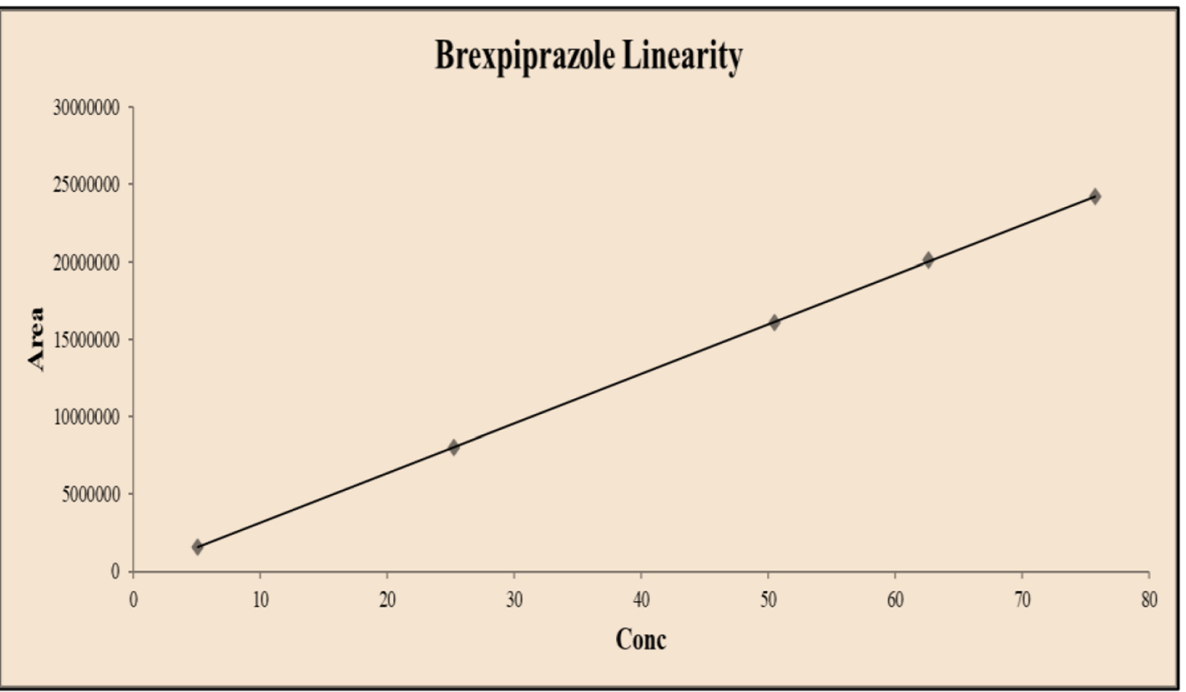

Fig. 10 Linearity graph of brexpiprazole

Table 14 Data for calibration curve of brexpiprazole

\begin{tabular}{ll}
\hline Parameters & Result \\
\hline Detection wavelength & $216 \mathrm{~nm}$ \\
Beer's law limit & $5.05-75.75 \mu \mathrm{g} / \mathrm{mL}$ \\
Slope & $1,620,101.119$ \\
Intercept & $-279,840.1481$ \\
Correlation coefficient $\left(\mathrm{R}^{2}\right)$ & 0.9999 \\
\hline
\end{tabular}

Table 15 Result of detection limit

\begin{tabular}{ll}
\hline Parameter & Result \\
\hline LOD & $0.64 \mu \mathrm{g} / \mathrm{mL}$ \\
LOQ & $1.95 \mu \mathrm{g} / \mathrm{mL}$ \\
\hline
\end{tabular}


Table 16 Result of robustness

\begin{tabular}{|c|c|c|c|c|c|c|c|c|}
\hline \multirow[t]{3}{*}{ Sr.no. } & \multirow[t]{3}{*}{ Parameter } & \multicolumn{6}{|c|}{ Observations } & \multirow[t]{3}{*}{ Limit } \\
\hline & & \multicolumn{2}{|c|}{ Changes in flow rate } & \multicolumn{2}{|c|}{ Change in wavelength } & \multicolumn{2}{|c|}{ Change in column oven temperature } & \\
\hline & & $\overline{1.2}$ & 0.8 & 219 & 213 & $\overline{32^{\circ} \mathrm{C}}$ & $28^{\circ} \mathrm{C}$ & \\
\hline 1 & Peak area response & $13,429,477$ & $20,188,069$ & $1,589,0163$ & $19,777,590$ & $16,118,641$ & $16,127,528$ & \\
\hline 2 & Theoretical plates & 3681 & 3639 & 3678 & 3667 & 3672 & 3653 & NMT 2000 \\
\hline 3 & Tailing factor & 1.34 & 1.34 & 1.33 & 1.34 & 1.33 & 1.34 & NMT 2.0 \\
\hline 4 & R.T. (min) & 3.54 & 5.32 & 4.24 & 4.23 & 4.23 & 4.23 & \\
\hline
\end{tabular}

\section{Discussion}

The aim of this project was to create a simple, reliable, precise, and appropriate RP-HPLC system using the Quality by Design (QbD) approach. DOE results, including ANOVA, diagnostic graphs, and model graphs, were examined for each factor. The effect of each factor on the response result was investigated in this result.

In terms of analytical method creation and validation, the results of all system suitability parameters were appropriate within the limits specified by applying $\mathrm{ICH}(\mathrm{Q} 2 \mathrm{R} 1)$ guidelines, indicating that the system is functioning properly and can provide accurate and precise results. The established method's analysis results were validated in terms of linearity, accuracy, precision, and robustness, as well as the detection and quantification limits.
The developed method has many advantages, according to Mondal et al., including reproducibility of findings, rapid interpretation, easy sample preparation, and improved selectivity and sensitivity. The developed method can be used for routine research in the pharmaceutical industry for the bulk drug brexpiprazole as well as the pharmaceutical dosage type since it is stable and reproducible and takes less time [10].

\section{Conclusion}

According to the above experimental results, this newly developed method for estimating brexpiprazole was found to be simple, precise, and accurate, with a shorter retention time that makes it more acceptable and cost effective, and it can be effectively applied for routine analysis in research institutions, quality control departments in industries, and approved testing laboratories.

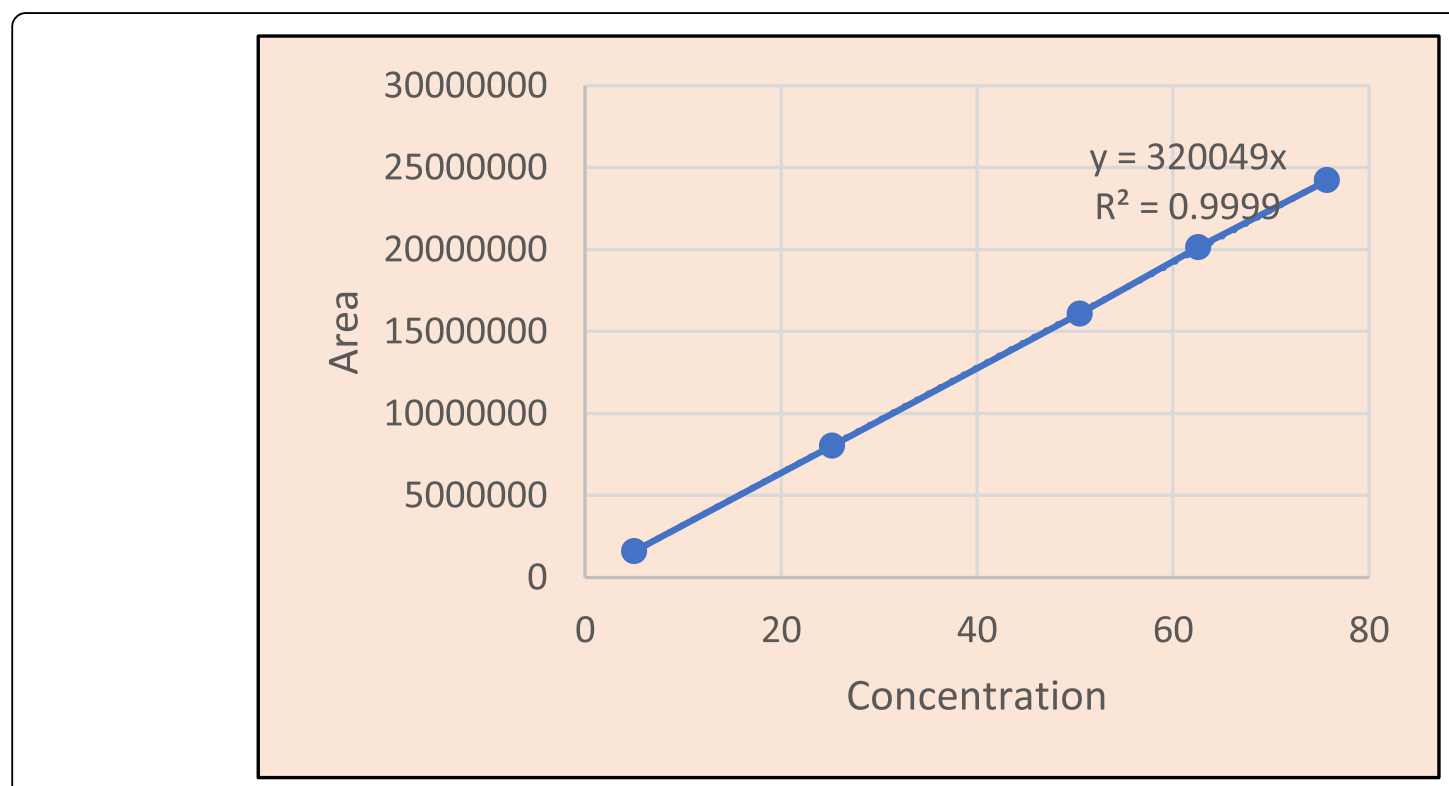

Fig. 11 Calibration curve of brexpiprazole for LOD and LOQ 


\section{Abbreviations}

RP-HPLC: Reversed-phase high-performance liquid chromatography; \%RSD: Percentage recovery; LOD: Limit of detection; LOQ: Limit of quantification; QbD: Quality by Design; USFDA: United States Food and Drug Administration; ICH: International Council for Harmonization of Technical Requirement for Pharmaceutical for Human Use; OPA: Orthophosphoric acid; DMF: Dichloromethane; DMSO: Dimethyl sulfoxide; $\mathrm{HCl}$ : Hydrochloric acid; PVDF: Polyvinylidene fluoride; ANOVA: Analysis of variance; API: Active pharmaceutical ingredient

\section{Acknowledgements}

Authors express their sincere gratitude to N.D.M.V.P. College of Pharmacy, Nashik, and Sanjivani College of Pharmaceutical Education and Research, Kopargaon, for continuous motivation, support, and guidance for research activity and for providing all required facilities to accomplish the entitled work.

\section{Authors' contributions}

R.N. contributed to literature survey and performed practical work and thesis typing, N.P. supported in performing experimental work, A.S. had contributed to guide the whole work, and P.B. and D.S. contributed to editing in thesis typing. The authors read and approved the final manuscript and approve the submission

\section{Funding}

Not applicable

\section{Availability of data and materials}

Data and material are available upon request.

• https://www.accessdata.fda.gov/drugsatfda_docs/label/2018/205422s003/bl. pdf

- https://www.clinicaltrialsarena.com/projects/rexulti-brexpiprazole-treatmentmajor-depressive-disorder-schizophrenia/

- www.drugbank.com

- https://www.drugs.com/monograph/brexpiprazole.html

\section{Declarations}

Ethics approval and consent to participate

Not applicable.

\section{Consent for publication}

Not applicable.

\section{Competing interests}

The authors declare that they have no competing interests.

\section{Author details}

'MVPs College of Pharmacy, Nashik-422 002, Department of Pharmaceutical Chemistry, Savitribai Phule Pune University, Pune, MS, India. ${ }^{2}$ SRE'S, Sanjivani College of Pharmaceutical Education and Research, Kopargaon, India.

Received: 24 February 2021 Accepted: 25 June 2021

Published online: 19 July 2021

\section{References}

1. Greig SL (2015) Brexpiprazole: first global approval. Drugs 75(14):1687-1697. https://doi.org/10.1007/s40265-015-0462-2

2. Rexulti ${ }^{\oplus}$ (brexpiprazole) [full prescribing information]. 2015.https://www.a ccessdata.fda.gov/drugsatfda_docs/label/2018/205422s003lbl.pdf Accessed 18 Jan 2016.

3. Stahl SM (2016) Mechanism of action of brexpiprazole: comparison with aripiprazole. CNS Spectr 21(1):1-6. https://doi.org/10.1017/S109285291 5000954

4. https://www.clinicaltrialsarena.com/projects/rexulti-brexpiprazole-treatmentmajor-depressive-disorder-schizophrenia/

5. Maeda et al (2014) Brexpiprazole I: in vitro and in vivo characterization of a novel serotonin-dopamine activity modulators. J Pharmacol Exp Ther 350(3): 589-604. https://doi.org/10.1124/jpet.114.213793
6. Hope J, Castle D, Keks NA (2018) Brexpiprazole: a new leaf on the partial dopamine agonist branch. Australas Psychiatry 26(1):92-94. https://doi.org/1 $0.1177 / 1039856217732473$

7. Sravani A, Naga Durga $\mathrm{CH}$, Divya U, Suneetha $\mathrm{CH}$, Suresh $\mathrm{P}$, Tirumaleswara Rao B (2017) Method development and validation for the estimation of brexpiprazole in drug substance by RP-HPLC method. Indo Am J Pharm Res 7(05):8560-8564

8. Bhawar HS, Thete S, Shinde GS (2019) Development and validation of stability indicating RP-HPLC method for estimation of brexpiprazole from bulk and tablet form. J Drug Deliv Therapeut 9(4):141-145

9. Jaiswal CC, Patel HU (2020) Development and validation of stability indicating RP-HPLC method for estimation of brexpiprazole in tablet. World J Pharmacy Pharm Sci 9(6):1568-1582

10. Mondal S, Kumar VG, Mondal P (2018) New spectrophotometric techniques for the estimation of brexpiprazole in tablet dosage form. Int J Pharm Sci Res 10(5):2151-2455

11. Patel P, Mashru R (2020) Design, optimization, and validation of chemometrics assisted spectrophotometric methods for simultaneous determination of brexpiprazole and aripiprazole

12. Pulusu VS, Routhu KC, Chikkaswamy SB (2019) Quantitative determination of brexpiprazole by RP-HPLC method. Pharmaceutica Analytica Acta 10(2):610 1-5

13. www.drugbank.com

14. https://www.drugs.com/monograph/brexpiprazole.html

15. ICH Harmonized Tripartite Guideline. (2009). Pharmaceutical development Q8(R2) International Conference on Harmonization of Technical Requirements for Registration of Pharmaceuticals for Human Use. http:// www.ich.org/fileadmin/public_web_site/ich_products/guidelines/quality/ Q8_R1/step4/Q8_R2_guideline.pdf

16. ICH Harmonized Tripartite Guideline. Quality risk management Q9 (2005) International Conference on Harmonization of technical requirements for registration of pharmaceuticals for human use. http://www.ich.org/filea dmin/Public_Web_Site/ICH_Products/Guidelines/Quality/Q9/Step4/Q9_ Guideline.pdf

17. ICH Harmonized Tripartite Guideline. Pharmaceutical quality systems Q10 (2008) International Conference on Harmonization of technical requirements for registration of pharmaceuticals for human use. http:// www.ich.org/fileadmin/public_web_site/ich_products/quidelines/quality/Q1 0/step4/Q10_guideline.pdf

18. Gundala A, Bharathi K, Prasad KVSRG (2018) Analytical quality by design approach in RP-HPLC method development for the assay of pitavastatin in tablet dosage form. Int J Pharm Sci Res 9(11):4992-5001

19. Bhatt DA, Rane SI (2011) QbD approach to analytical RPHPLC method development and its validation. Int J Pharm Pharm Sci 3(1):179-187

20. International Conference on Harmonization of technical requirements for registration of pharmaceuticals for human use $\mathrm{ICH}$ harmonized tripartite guideline validation of analytical procedures: text and methodology Q2(R1) Validation. https://www.ich.org/page/quality-guidelines\

21. Vidushi Y, Meenakshi B (2017) A review on HPIC method development and validation. Res J Life Sci, Bioinform, Pharm Chem Sci 2(6):178

22. Pendhbaje NS, Nirmal RV, Jamdhade AA, Pathan SM (2021) Method development and validation by HPLC: a brief review. Res Rev: J Pharm Sci 12(1):27-39p

23. Bose A (2014) HPLC calibration process parameters in terms of system suitability test. Austin Chromatogr 1(2):1-4

24. Sabir AM (2013) HPLC method development and validation -a review. In Res J Pharm 4(4):39-46

25. Pendbhaje NS, Jamdhade AA, Pathan SM, Nirmal RV (2021) A review on quantification of brexpiprazole in its bulk and pharmaceutical dosage form by various analytical methods. Int J Pharm Res Appl 6(1):1118-1132

\section{Publisher's Note}

Springer Nature remains neutral with regard to jurisdictional claims in published maps and institutional affiliations. 